Tér és Társadalom 2. évf. 1988/1. 79-80. p.

\title{
NYILT TÉR
}

\section{MIN DOLGOZIK „A HELYI TÁRSADALOM“ CSOPORT?}

1980-ban az MSZMP KB Társadalomtudományi Intézete olyan vállalkozásba kezdett, amely iránt a területi kérdésekkel foglalkozó kutatók, szakemberek méltán érdeklödnek. BÖHM ANTAL és PÁL LÁSZLÓ vezetésével megindult a helyi társadalmak empirikus kutatása. BÖHM ANTALt e kutatás körülményeiról és eredményeiröl kérdeztem.

Kérdező: Milyen igényekböl táplálkozott, hogy merült fel a helyi társadalom kutatásának ötlete?

Böhm A.: PÁL LÁSZLÓval a hetvenes évek közepétôl foglalkoztunk az ingázókkal. E munkásréteg sajátos problémái egyenesen vittek bennünket a helyi társadalom kérdésköréhez. Amikor mi erröl gondolkodni kezdtünk, akkor még kevésbé volt használatos Magyarországon ez a fogalom. Az izgatott bennünket elsösorban, hogy milyen tényezőkben is jelennek meg a települési egyenlótlenségek, s ezek hogyan formálják a lakosságot, egyáltalán milyen lehetőségei vannak a lakópolgárnak arra, hogy beleszóljon a helyi döntési folyamatokba. Ekkortájt erósödött föl a vita a településfejlesztési politika körül. Többen joggal hangsúlyozták: Magyarországon talán a legkeményebb egyenlótlenségeket a településstruktúra hordozza. S megindultak olyan társadalmi mozgások is, amelyek a településekhez kötódtek. Gondolok itt az ökológiai mozgalmakra, azokra az önállósodási törekvésekre, amelyek már nem engedték, hogy például a települések nevét elvegyék, amelyek megpróbáltak saját gazdasági bázist teremteni, és igy tovább. Ezek a körülmények szerencsés hátteret biztosítottak a helyi társadalom kutatásának beinditásához. Elsö vizsgálatunk Dabas térségében történt, a volt dabasi járás hat településének helyi társadalmi müködését elemeztük.

Kérdezó: A kutatások indításakor milyen fogalmi, módszertani problémák merültek fel? A kutatás első publikált kötetében még elsősorban elméleti, módszertani problémákkal foglalkoztatok.

Bóhm A.: Lényegében értelmezni kellett a helyi társadalom fogalmát, vagy legalábbis olyan fogalomhoz kellett jutni, amit operacionalizálni lehetett a kutatások számára. A rendelkezésre álló polgári szakirodalom adaptálása csak erőteljes korrekciókkal történhetett. PÁL LÁSZLÓ kidolgozott egy dimenziórendszert. A részvétel, a kötődés, az elégedettség, a perspektíva, az integráció és a kooperáció dimenziója olyan fogalmi hálót jelentett, amelynek keretében a helyi társadalom vizsgálható. Amikor az első tanulmánykötetet kiadtuk, még szinte naivan kerestük az elméleti fogódzókat. Ma már sokkal világosabban látjuk, hogy a helyi társadalom nagyon bonyolult képződmény, amelynek többféle megközelítési módja lehetséges. Egyrészt meg lehet közelíteni a társadalmi struktúrával. Feltételezhető, hogy a társadalmi szerkezet újratermelódése a lokalitásban megragadható. Ebben az értelemben a helyi társadalom egy közvetítörendszer a nagy társadalom és az egyén, illetve az egyén 
különféle közösségszerveződési típusai között. Eleinte azt feltételeztük, hogy a kis helyi társadalom mechanikusan leképezi a nagy társadalmat. Ez nem igy van. Kiderült, hogy egy-egy településen egészen más „helyi értéke” van az adott egyénnek, csoportnak, közösségnek, mint a "nagy társadalomban". A tipizálás a közösségszerveződés mentén valósítható meg; a közösségen kívüli, szétesó, vegetáló társadalmi léttöl kezdve a tudatosan szervezett, integrált helyi közösségig sokféle típusa lehet egy-egy helyi társadalomnak. Az ideáltipus természetesen egy olyan erỏs, szerves he. Iyi társadalom, amelyik képes önmagát megvédeni, érdekeit kifejezni. Ennek persze az a feltétele, hogy ebben a helyi társadalomban lakópolgárok legyenek jelen, akik rétegérdekeiket megfelelő fórumokon meg tudják jeleníteni. Jelen pillanatban a magyar társadalom többsége kialakulatlan vagy vegetáló lokális közösségekhez tartozik. Vannak viszont olyan helyi társadalmak is, amelyekben már erőteljes integrációs mozgások indultak meg.

Kérdezó: Itt a helyi társadalom kutatásának egy újabb dimenziójához értünk, amit talán ahhoz az ominózus kérdésfeltevéshez lehet kötni, hogy van-e helyi hatalom Magyarországon? A kibontakozó helyi politikai mozgások milyen intézményes kereteket kapnak?

Bóhm A.: Vizsgálataink másik csomópontja ez. Véleményem szerint van heIyi hatalom, csak nem úgy funkcionál, ahogy funkcionálhatna. A hatalom oldaláról való megközelités a politikai érdekérvényesítés, érdekütköztetés, konfliktus sajátosságait elemzi.

Kérdező: A kutatások több térségben, településen folynak. Találtatok-e olyat, amelyik szervezódni képes, „,inktakt” helyi társadalmat mondhat magáénak?

Böhm A.: Talán azok a települések (Tiszakécske, Szombathely, Siómaros stb.), ahol a helyi erők, társadalmi csoportok, vezetők felvállaltak valamit a település számára, ahol a vezetés megpróbálta a lakosság érdekében a gazdasági-szellemi eröket integrálni, s ennek elónyeit kamatoztatni.

Kérdezb́: Úgy tünik - a példákból is -, hogy erősen szubjektiv tényezőkhöz kötődik az, hogy a település vagy bármilyen helyi közösség képes-e érdekeit érvényesíteni.

Bóhm A.: Ez azért van így, mert a hatalmi struktúra egycsatornás, és meganynyi paternalisztikus elemet hordoz. Ahogy egy üzem, gazdaság többnyire akkor boldogul, ha van egy jó vezetôje, igy van ez a települések esetében is... Bár én úgy tapasztalom, hogy a lakosság is egyre inkább mozdulni akar. Különösen a fiatalokra, az ér. telmiségiekre lehet számítani. A kisebb falusi településeken azonban alig van helyi értelmiség, s ezek ebböl a szempontból is hatalmas hátrányban vannak. Vizsgálataink alapján egyre in kább kibontakozik egy harmadik dimenzió, amit nevezhetünk szociálpszichológiainak is. Ebben a megközelítésben a helyi társadalom nem más, mint egy állampolgári, lakópolgári magatartást alakító, formáló tén yező, $s$ ebben válik fontossá az egyéni aktivitás, az ismeretszint, az attitïd kérdése.

Kérdező: A korábban elsősorban [Dabas térségében folyó vizsgálatokat sikerült-e területileg bóvíteni?

Bóhm A.: Mintaértékủ együttmüködést sikerült kialakítani a Müvelődési Minisztérium Vezetőképző és Továbbképző Intézetével, valamint a Múvelödéskutató Intézettel. Igy módunk nyilik kis, sőt nagyvárosok kutatására is. Közösen próbáljuk 
Györ, Esztergom, Pápa, Orosháza és Kaposvár helyi társadalmát vizsgálni. A kaposvári felvételen túl vagyunk, most dolgozzuk fel a kérdöiveket, s úgy tünik, izgalmas összehasonlítási lehetöségünk lesz a falusi és városi térségek helyi társadalmát illetöen. Az emberek közötti kapcsolatok például szétesöbbek a városi térségekben, viszont a participációs esélyek nagyobbak. Ugyanakkor azt is sejteni lehet már, hogy a helyi vezetők személyéről és tevékenységéről meglévő ismeretek tekintetében nincsenek markáns különbségek.

Kérdező: Ez azt jelentené, hogy a lakosság politikai ismeretszintje lényegében nem függ a helyi tájékoztatáspolitikától? Az utóbbi időben azt tapasztalom, hogy felerósödtek a helyi nyilvánosság, a helyi tájékoztatás intézményei iránti igények. Ebben a kérdésben különbözöek az esélyei a kis és nagyobb településeknek. Kiépülnek a kábeltelevíziók, helyi lapok jelennek meg, ugyanakkor a helyi döntések még mindig egy szúk elit körében születnek. Technikai kérdés az, hogy van-e helyi újság, vagy kábeltelevizió, amíg a politikai kultúra, illetve a politikai döntési folyamatok nyilvánossága nem fejlödik.

Böhm A.: Én úgy érzem, tényleges demokratizálást indíthatna el, ha volna he. lyi nyilvánosság, helyi sajtó, kábeltelevizió. Viszont azt láttuk, hogy például a megyei lapok egyáltalán nem helyi lapok, hanem a központi orgánumok másolatai. Persze az is tarthatatlan, hogy egy termelöszövetkezetnek vagy ipari üzemnek sokkal inkább van lehetősége egy-egy lapot fenntartani, mint magának a településnek. Sokkal jobb lenne, ha a településnek lenne egy termelöszövetkezete, állami gazdasága vagy nagyüzeme. Jelenleg e képletnek in kább az ellenkezője a jellemzö. A politikai kultúra megteremtése szempontjából is nagyon fontos lenne a helyi újság. Bölcsészkoromban találkoztam a Sümegi Népújsággal, amelyikben a 30-as években Németh László novellákat közöltek. Ma sem Sümegi Népújság, sem Németh László nincsen. Gondoljuk végig, hogy tanulhatunk lakópolgári, állampolgári politikai magatartásszabályokat, ha nem voltak ilyen tradicióink, illetve amelyek voltak, sorra kihaltak.

Kérdezô: Fellelhetők-e egyáltalán tradicionális elemek a helyi közéletben, illetve a helyi társadalmak szervezödési folyamatában. Vannake mentalitásbeli vagy nemzetiségi különbségek a helyi közösségekben, vannak-e ilyen kimutathàtó sajátosságok?

Böhm A.: Ez meglehetösen ellentmondásos, mert igaz az, hogy a korábbi társadalmi struktúráknak irmagja sem maradt, viszont az is igaz, hogy a tradíciók mélyen beépültek az emberekbe, szinte a génjeikben hordozzák óket. Például az, hogy valaki protestáns vagy katolikus környékról jött-e, erösen befolyásolja politikai kultúráját, toleranciakészségét, vitakedvét. Dabas környékén találkozunk nemzetiségi problémákkal is. Sári például szlovák-lakta falu volt, s máig kiválik a többi környékbeli település közül. Ez természetesen egyfajta értéket is jelent, ami megjelenik a munkakultúrában vagy a mentalitásban. A struktúrák valószínúleg sokkal keményebben örzik a tradiciókat, mint korábban gondoltuk. Hiszem, hogy vizsgálni kell azt, vajon a változtatások milyen valóságos változásokat hoztak, s mik a tradicionálisan megörzött elemek a társadalomban. Erre a szempontra is ügveltünk a vizsgálatok során. Persze, erre több figyelmet kellene fordítani. Aggódom, hogy elkallódnak azok a településsorsok, amelyek az elmúlt 40 évet dokumentálnák. A falukrónikák vezetése csak néhány éve folyik, s alig vannak olyan vállal kozók, akik a korábbi adatok alapján 
településmonográfiákat készitenének. Ezekre az elemzésekre nem csak a konkrét vizsgálatok megalapozása miatt van szükség, egész társadalmi berendezkedésünkhöz, politikai rendszerünkhöz közelebb visznek ezek az ismeretek.

Kérdezö: Igen, ez nagyon fontos kérdés. Vajon egy makroszemléletü társadalomirányításban hogyan hasznosulhatnak a lokalitásokról szerzett információk. Hiszen ez a beszélgetésünkböl kiderült, hogy a helyi társadalmak olyan sokrétüek, hogy aligha összegezhetök valamiféle egységes, a központi politika számára kezelhetö képpé.

Bóhm A.: A döntéshozók egyre világosabban látják, hogy a makrofogalmakkal nagyon kevéssé lehet bármit kezdeni. "Munkás, paraszt, értelmiség”, „falu-város", kiüresedett fogalmak. A társadalom sokkal differenciáltabb, ezért reális döntés csak az lehet, amelyik figyelembe veszi e különbségeket. A finomabb társadalmi szerkezethez sok támpontot adhat a lokális és regionális nézőpont. A regionalitást egyéb. ként azért kevertem bele a dologba, mert meggyőződésem, hogy méltatlanul elhanyagolt területe a szociológiának $s$ a magyar közigazgatásnak is. Miközben hajtogatjuk a regionális politika szükségességét, addig a megyehatárok szabnak korlátot min. denféle progressziv mozgásnak.

Kérdezó: A kutatás témája egyértelmúen állásfoglalás amellett, hogy a demokrácia, az egyén társadalomhoz való kapcsolódása egyik legfontosabb színtere a lakóhely. A gazdaság, gazdasági hatékonyság s az ember a maga életkörülményeivel, lakóhelyével bizonyos fajta párharcot vív, amiben eleddig, úgy tünik, az ökonomista szempontok győzedelmeskedtek, hiszen még a látszólag az infrastruktúra elosztását megalapozó elsö OTK is elsősorban a termelés céljait (sőt az ipari termelés céljait) szolgálta. Milyen esélyei vannak a közösség lakóhelyi szervezödésének?

Bóhm A.: Ebbe a kérdésbe mindig beleütközünk. Olyan mértékben koncentrálódott minden életfeltételünk a munkahelyen, hogy már a magánéletünk is ott zajlik lassan. Sok lakóhely teljesen kiürült, alvóvárosi vagy falusi funkciót öltve. Az utóbbi időben azonban két folyamat is a lokalitás felértékelödését szolgálja. Egyrészt a munkahelyek modernizációs, teljesítménycentrikus orientációja következtében, igyekeznek mindenféle sallangtól megszabadulni, így a kulturális, oktatási, társadalmi tevékenységek munkaidön kívülre szorulnak. Ezt én csak helyeselni tudom. Másrészt az általános demokratizálódási törekvések terepe is egyre inkább a lakóhely lehet. Tehát visszaszerezheti korábban elvesztett pozícióit.

Kérdezó: Vajon e funkciókat egy tekintélyében, hatáskörében, anyagi kapacitásában felerösített helyi politika fogadhatja?

Böhm A.: Ez természetesen gyökeres változásokat igényel. Meg kell változtatni a redisztributív eloszlás jelenlegi rendjét, amiben már vannak bizonyos elörelépések. De változtatni kellene a közigazgatási struktúrán is. Kisebb közigazgatási egységeket feltételező irányítási hálózatra lenne szükség, valahogy úgy, ahogy BIBÓ ISTVÁN elképzelte. Persze mindjárt felmerül az aggály, hogy a decentralizáció a központi államhatalom rovására történik. Nern győzöm hangsúlyozni, hogy a decentralizálás egy nagyon erós központi hatalmat feltételez. Már EÖTVÖS azt írta, hogy minél erősebbek a lokális hatalmak, annál erösebb maga a rendszer.

Kérdező: Lényegében tehát ésszerủ munkamegosztásról van szó...

Böhm A.: Igen, s arról, hogy ez teret adna az autonóm közösségszervezési törekvéseknek, s nem falakat állitana elébük. A lakópolgárokra biznák azt, hogy mit 
akarnak csinálni a lakóhelyükön. Ez a lehetöség óriási mértékben javítaná az állampolgárok életminóségét. Sok esetben még gazdasági nyavalyáink kompenzálása is elképzelhetó lenne, s ez még gazdasági eröforrásokat sem vonna el, inkább csak a gondolkodásunk megváltozását igényelné.

Kérdező: Véleményed szerint a kutatásotok társadalompolitikai jelentőségével összhangban vane .,tudománypolitikai helyzete" vagy még direktebben anyagi támogatása?

Böhm A.: A társadalomtudományon, illetve a szociológián belül, úgy érzem, polgárjogot nyert a vizsgálatunk. Erősödő szakmai és politikai érdeklődés van kutatásaink iránt. Persze az más kérdés, hogy időnként gyakorló politikusok értetlenségével is találkozunk. Azt mondják "minek ez a polgári fogalom”, „miért kell a társadalmat szétszabdalnunk”, „elöbb a globális problémákat kell megoldanunk, s azután a helyit" stb. Sokan nem érzik még azt, hogy éppen a globális gondolkodás eredményessége miatt nélkülözhetetlen információkról van szó. Voltak már Magyarországon modernizációs kísérletek, de mindig idegen minták alapján. Valószínú ott tévedtünk, hogy nem építettük be a tradiciókat, nem organikusan közelítettünk a társadalom és gazdaság modernizációjához. Kölcsönös determinációról van tehát szó. Csak akkor gondolkodhatunk nemzeti és világméretekben, ha ismerjük a lokalitás problémáit is.

PÁLNÉ KOVÁCS ILONA 